\title{
EFFECT OF STEAM THERMAL TREATMENT ON THE DRYING PROCESS OF Eucalyptus dunnii VARIABLES
}

\author{
Elias Taylor Durgante Severo ${ }^{1 *}$, Ivan Tomaselli², Fred Willians Calonego ${ }^{1}$, \\ André Luiz Ferreira ${ }^{3}$, Lourival Marin Mendes ${ }^{4}$
}

*Corresponding author: severo@fca.unesp.br

\begin{abstract}
The aim of this study was to evaluate the effect of steam treatment prior to drying on the initial moisture content, moisture gradient, and drying rate in Eucalyptus dunnii Maiden wood. Boards were steamed at $100^{\circ} \mathrm{C}$ for $3 \mathrm{~h}$ after $1 \mathrm{~h}$ of heating-up. Part of these boards was dried in a drying electric oven at $50^{\circ} \mathrm{C}$, and part was dried at kiln. The results showed that the steaming prior to drying of wood: (1) significantly reduced by $9.2 \%$ the initial moisture content; (2) significantly increased by $6.2 \%$ the drying rate; (3) significantly decreased by 15.6 and $14.8 \%$ the moisture gradient between the outer layer and the center of boards and between the outer and intermediate layers of boards, respectively. Steamed boards when dried in an oven showed drying rate of 0.007065 whereas in kiln were 0.008200 and 0.034300 from green to 17 and 17 to $12 \%$ moisture content, respectively. It was demonstrated that the steaming prior to drying can be suitable for reduces the drying times of this kind of wood.
\end{abstract}

Key words: Drying rate, eucalipto, moisture gradient, steaming prior to drying.

\section{EFEITO DO TRATAMENTO TÉRMICO COM VAPOR NAS VARIÁVEIS DO PROCESSO DE SECAGEM DE Eucalyptus dunnii}

RESUMO: Objetivou-se, neste estudo, avaliar o efeito do tratamento de vapor preliminar à secagem sobre o teor de umidade inicial, gradiente de umidade e taxa de secagem da madeira de Eucalyptus dunnii Maiden. Tábuas foram vaporizadas à $100^{\circ} \mathrm{C}$ após 1 hora de aquecimento inicial. Parte dessas tábuas foi seca em uma estufa elétrica à $50^{\circ} \mathrm{C}$, e outra parte foi seca em estufa de secagem convencional. Os resultados mostraram que a vaporização preliminar à secagem da madeira: (1) reduziu significativamente o teor de umidade inicial em 9.2\%; (2) aumentou significativamente a taxa de secagem em 6.2\%; (3) diminuiu significativamente o gradiente de umidade entre a camada externa e o centro das tábuas em $15.6 \%$, e entre a camada intermediária e o centro das tábuas em $14.8 \%$. As tábuas vaporizadas quando secas em estufa elétrica apresentaram taxa de secagem de 0.007065, enquanto que em estufa convencional foram 0.008200 e 0.034300 desde verde a $17 \%$ e de $17 \%$ a 12\% de umidade, respectivamente. Ficou demonstrado que a vaporização preliminar à secagem pode ser responsável pela redução no tempo de secagem da madeira dessa espécie.

Palavras-chave: Taxa de secagem, eucalyptus, gradiente de umidade, vaporização preliminar à secagem.

\section{INTRODUCTION}

The introduction of Eucalyptus dunnii in Brazil is relatively recent, dated from 1964 , being that the first plantations were made on an experimental basis by pulp and paper companies. Given the scarcity of wood for furniture-making sector and construction industry, particularly in South and Southeast regions from Brazil, the $E$. dunnii has been highly promising, as consequence of its fast growth, good stem form, and great adaptability to cold climates, and frost resistance. E. dunnii already demonstrated support temperatures at $-5^{\circ} \mathrm{C}$, and presents potential from trade reforestation mainly in the southern region of Brazil (FOOD AND AGRICULTURE ORGANIZATION OF THE UNITED NATIONS - FAO, 1981; GOLFIARI; PINHEIRO NETO, 1970).
However, use of this wood has caused many frustrations in the timber industry due to the sawn and drying defects, leading to considerable loss of raw materials and consequent economic losses, as well as other species of eucalypt. The main frustrations regarding the use of this wood specie, particularly as lumber, are due primarily to their intrinsic characteristics such as: growth stress, high shrinkage, slow drying, high moisture gradient, surface cracks, and collapse during drying (CALONEGO et al., 2010; CALONEGO; SEVERO, 2007; SEVERO et al., 2010; SOUZA et al., 2012).

During all phases of wood processing, the drying process is the best way to add value to the product. Drying eucalypts woods is considered to be slow and difficult because of their low permeability mainly in the heartwood, which is responsible for their sharp moisture gradient and

\footnotetext{
${ }^{1}$ Universidade Estadual Paulista Júlio de Mesquita Filho - Botucatu, São Paulo, Brazil

${ }^{2}$ Universidade Federal do Paraná - Curitiba, Paraná, Brazil

${ }^{3}$ Amata do Brasil - São Paulo, São Paulo, Brazil

${ }^{4}$ Universidade Federal de Lavras - Lavras, Minas Gerais, Brazil
}

Cerne, Lavras, v. 19, n. 4, p. 637-645, out./dez. 2013 
the consequential formation of drying stresses. During drying, the superficial layers of boards are under tensile stress, while the center is under compression, causing superficial and end-crack and warping (CALONEGO; SEVERO, 2004, 2007; SEVERO, 2000; SOUZA et al., 2012; VERMAAS, 1995).

Steaming wood is a technique that may solve the drying problems, and it is applied for a variety of other purposes, including to change color, reduce growth stress levels, improve dimensional stability, increase permeability, reduce the initial moisture content, increase drying rate, and reduce the moisture gradient and drying defects (CALONEGO et al., 2010; CALONEGO; SEVERO, 2004, 2007; CHAFE, 1990; HILDEBRAND, 1970; KOLLMANN; CÔTE JUNIOR, 1968; MACKAY, 1971; SEVERO et al., 2010; SIMPSON, 1975, 1976; WEIK et al., 1984; ZHANG; CAI, 2008).

Steaming Quercus sp. wood at $100^{\circ} \mathrm{C}$ for $4 \mathrm{~h}$ increases the longitudinal permeability of wood by 20 times (ELLWOOD; ECKLUND, 1961). This technique provided a moisture content loss during the heating process by increasing the temperature and the expansion of water bubbles inside the wood. Later, during cooling, more moisture was lost by evaporation (ELLWOOD; ERICKSON, 1962). The steamed wood has partially hydrolyzed the pit membrane, reducing pit aspiration and, consequently, increasing its permeability (KININMONTH, 1971; MATSUMURA et al., 1999; NICHOLAS; THOMAS, 1968; ZHANG; CAI, 2008).

In addition to permeability, the vapor diffusion is also an important factor in drying, and in reducing drying time. Steaming of Eucalyptus regnans and Ceratopetalum apetalum increases the diffusion coefficient and recovery the collapse after wood drying (MACKAY, 1971).

Quercus rubra wood steamed at $100^{\circ} \mathrm{C}$ for $4 \mathrm{~h}$ showed a 23\% decrease in drying time (SIMPSON, 1976). Similar results were obtained after steaming Eucalyptus sp., which showed a 35\% reduction in drying time from the green stage up to $15 \%$ moisture content (CAMPBELL, 1961). Eucalyptus pilularis wood pre-steamed at $100^{\circ} \mathrm{C}$ for $3 \mathrm{~h}$ showed a decrease in drying rate between 7 and 16\% (ALEXIOU et al., 1990).

Several hypotheses have been proposed to explain the mechanism by which the drying rate increases in steamed wood. The explanations include (1) an increase in the permeability of the warts layer and accessibility to the $\mathrm{S}_{3}$ layer from the cell wall, (2) acid hydrolysis of the chemical components from the cell walls, and (3) the mobilization and partial removal of extractives during steaming allow greater access of water molecules to cell walls resulting in more rapid radial and tangential diffusion during wood drying (ALEXIOU et al., 1990; KININMONTH, 1971; MACKAY, 1971; SALUD, 1976; MATSUMURA et al., 1999; ZHANG; CAI, 2008).

Steaming of Hem-fir wood at $100^{\circ} \mathrm{C}$ for $5-20 \mathrm{~h}$ significantly reduced the moisture gradient with increasing thermal treatment time (AVRAMIDIS; OLIVEIRA, 1993). The use of pre-steaming on E. pilularis wood caused a $12.2 \%$ reduction in the moisture gradient between the center and the surface of the boards during the first 8 days of drying, and a reduction in the moisture gradient of 5.2\% throughout the drying process (ALEXIOU et al., 1990).

Steaming reduced the occurrence of defects during the drying process of Eucalyptus sp. and this result is associated with reducing the moisture gradients in the boards (GUOXING et al., 2003). Pre-steamed $E$. pilularis wood showed a 53\% reduction in surface cracks when compared to the untreated material (ALEXIOU et al., 1990). Steaming wood also reduced end-cracks up to $43.4 \%$ in Eucalyptus grandis boards (CALONEGO; SEVERO, 2004). The boards removed from pith to bark direction of steamed E. grandis logs showed a significant reduction and homogenization of drying defects (CALONEGO; SEVERO, 2007).

Thus, the objective of this study was to evaluate the effect of steaming on the initial moisture content, the moisture gradient, and the drying rate of E. dunnii wood.

\section{MATERIAL AND METHODS}

\subsection{Collection of material}

In this study, wood from E. dunnii trees with 16-yearold from the region of Colombo, Paraná, Brazil under coordinates $25^{\circ} 19^{\prime} 16^{\prime \prime} \mathrm{S}$ and $49^{\circ} 09^{\prime} 31^{\prime \prime} \mathrm{W}$ were utilized.

Eleven trees were felled and sectioned into $2.7 \mathrm{~m}$ logs. The logs with diameters between 20 and $30 \mathrm{~cm}$ were cut into band saw. The flat sawn boards were selected in this study. The boards were cross-cut sawed and surfaced on both faces. This material was divided in two charges to be dried in electric oven and in kiln of the Department of Engineering and Rural Technology, UFPR, Curitiba, PR, Brazil.

The boards of lot 1 were cut with dimensions of $25 \mathrm{~mm} \times 75 \mathrm{~mm} \times 2.60 \mathrm{~m}$ and, subsequently, were divided in half to obtain two-paired test samples with approximately $1.0 \mathrm{~m}$ long. The boards' cross-sections were sealed with a synthetic resin to avoid moisture loss by axial direction of the pieces.

Cerne, Lavras, v. 19, n. 4, p. 637-645, out./dez. 2013 
Part of the paired boards was kept in its original condition (untreated board), and the other half was reserved for steaming prior to drying (steamed board). The steaming treatment was conducted under saturated steam at $100^{\circ} \mathrm{C}$ for $3 \mathrm{~h}$ after $1 \mathrm{~h}$ of heating-up as recommend by Alexiou et al. (1990), Campbell (1961) and Simpson (1976).

The lot 2 consisted of steamed boards with the same dimensions of lot 1 , which after having their cross-sections sealed with a synthetic resin were dried in a kiln.

\subsection{Drying process of wood}

\subsubsection{Drying in electric oven}

Both the untreated and the steamed boards were marked into equal samples, each containing the sections " $\mathrm{x}$ " and " $\mathrm{y}$ " and a zone called discard with lengths of 10 , 15, and $25 \mathrm{~mm}$, respectively, as shown in Figure 1.

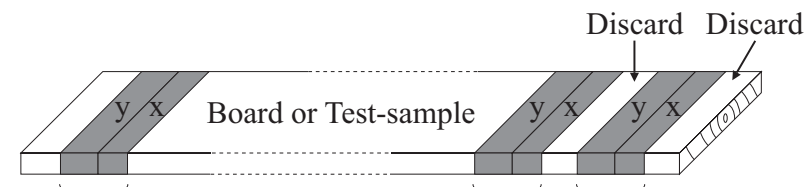

Section 13

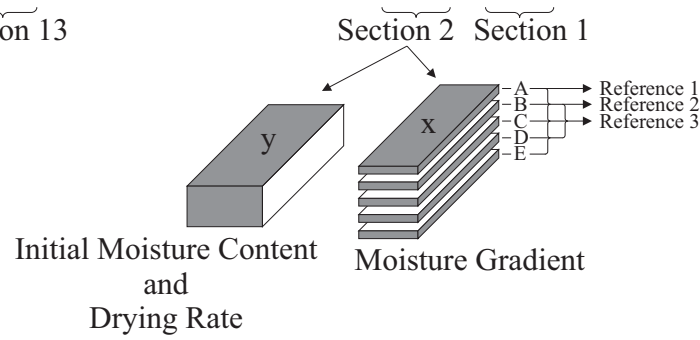

Section 2 Section 1

Figure 1 - Outer layer for obtaining the sections and " $x$ " and "y" sub-samples from paired boards.

Figura 1 - Esquema de obtenção das secções " $x$ " $e$ " $y$ ” de tábuas pareadas.

Untreated and steamed boards were dried at $50^{\circ} \mathrm{C}$ in an electric oven without fan. Periodically, the oven was discharged to remove the "x" and " $y$ " sections. Soon after the removal of these sections, the boards' cross-sections were sealed and replaced in the oven.

2.2.2 Determination of boards' initial moisture content and drying rate

Initial moisture content was determined from first " $y$ " section removed of untreated and steamed boards before drying in an electric oven, as shown in Figure 1.

Every 24 hours, the weights of the "y" sections from untreated and steamed boards were determined on a balance with $0.01 \mathrm{~g}$ accuracy and were then dried in a electric oven at $103 \pm 2^{\circ} \mathrm{C}$ to determine their oven-dry weight. Thus, it was possible to determine the moisture content of all " $y$ " sections removed during the drying process.

As the drying rate refers to the percentage of evaporated water in a given period, it is represented by the angular value from the linear regression curve, adjusted to represent the wood moisture content as a function of its drying time, as shown in equation 1 :

$\ln u=b-A * t$

where: $\ln u$ - logarithm of the wood moisture content, \%; $b$ - coefficient from the linear regression that represents the wood drying curve; $A$ - angular coefficient from the linear regression that represents the drying rate; $t$ - drying time, hours.

\subsubsection{Determination of boards' moisture gradient}

To determine the moisture gradient, the weights of the " $x$ " sections from untreated and steamed boards were initially verified within an accuracy of $0.01 \mathrm{~g}$ and, subsequently, they were laminated into five equal parts in the thickness direction, as shown in Figure 1.

The moisture content from wooden laminas was determined based on the oven-dry weight. The average moisture content was calculated across laminates equidistant from the center of each section. Thus, "reference 1" indicates the average of wooden laminas $A$ and E, "reference 2" indicates the average of wooden laminas B and D, and "reference 3" indicates wooden lamina $\mathrm{C}$. The moisture gradient was calculated between references 3 and 1 and also between 3 and 2 .

As the sections " $x$ " from steamed boards dried faster than the untreated boards, and considering that the comparisons between moisture gradients can only be performed at the same moisture content, it was necessary to identify and compare sections with the same moisture content or around $1.5 \%$ variation between untreated and steamed boards.

The treatments were arranged in which the factor was steaming (two levels, with and without steaming). To determine the significance of differences between means, paired $t$ tests at a probability of $95 \%$ were used.

\subsection{Determination of boards' drying rate in kiln drying}

A load with 50 steamed boards was dried in the conventional kiln with dimensions of $0.8 \mathrm{~m} \times 1.0 \mathrm{~m} \times 4.0$

Cerne, Lavras, v. 19, n. 4, p. 637-645, out./dez. 2013 
$m$ in width, height, and length. The aim of this drying was to verify the effect of thermal treatment by steam on drying rate from E. dunnii boards on the conditions of drying kiln. The drying schedule as shown in Table 1 was used.

Table 1 - Drying schedule to boards of E. dunnii.

Tabela 1 - Programa de secagem para tábuas de E. dunnii.

\begin{tabular}{lcccccc}
\hline $\begin{array}{l}\text { Moisture } \\
\text { content }(\%)\end{array}$ & $\begin{array}{c}\text { TD } \\
\left({ }^{\circ} \mathrm{C}\right)\end{array}$ & $\begin{array}{c}\text { TW } \\
\left({ }^{\circ} \mathrm{C}\right)\end{array}$ & $\begin{array}{c}\text { RH } \\
(\%)\end{array}$ & $\begin{array}{c}\text { EMC } \\
(\%)\end{array}$ & $\begin{array}{c}\text { Time } \\
(\mathrm{H})\end{array}$ & DP \\
\hline Pre-steaming & 100 & 100 & 100 & --- & 3 & --- \\
Up to 50\% & 40 & 37.5 & 85 & 17 & --- & 2,9 \\
$50-40 \%$ & 43 & 40 & 84 & 16.2 & --- & 2,8 \\
$40-30 \%$ & 45 & 41 & 79 & 14.2 & --- & 2.5 \\
$30-22 \%$ & 50 & 45 & 74 & 12.6 & --- & 2.1 \\
$22-17 \%$ & 55 & 44 & 51 & 7.7 & --- & 2.5 \\
Recovery & 100 & 100 & 100 & --- & 5 & -- \\
from collapse & & & & & & \\
Up to 15\% & 55 & 44 & 51 & 7.7 & --- & 2.1 \\
$15-12 \%$ & 60 & 47 & 47 & 6.9 & --- & 1.7 \\
\hline
\end{tabular}

Where Td - temperature of dry bulb, ${ }^{\circ} \mathrm{C} ; \mathrm{Tw}$ - temperature of wet bulb, ${ }^{\circ} \mathrm{C} ; \mathrm{RH}$ - relative humidity, $\%$; EMC - equilibrium moisture content, \%; DP - drying potential.

The drying rate of the boards load was determined based on the weight loss by a gravimetric system equipped with a load cell of $500 \mathrm{kgf}$ capacity coupled on the structure of the kiln. Some samples of the boards load were selected to determination dry weights and adjust the moisture content during drying process. The linear regression model was used to estimate the drying rate from E. dunnii boards.

\section{RESULTS AND DISCUSSION}

\subsection{Effect of steaming on the initial moisture content}

Table 2 shows the average values for the initial moisture content to untreated and steamed boards from E. dunnii.

As can be seen in Table 2, the initial moisture content in untreated boards was higher than in steamed boards. It was verified that the steamed caused a significant average decrease in the initial moisture content of $9.2 \%$.

This reduction in moisture content is due to the drying process that occurs in the wood, even in environments saturated with humidity when the timber is subjected to steaming at atmospheric pressure (CHAFE, 1990; HILDEBRAND, 1970; KOLLMANN; CÔTE
Table 2 - Effect of pre-steaming on the initial moisture content of E. dunnii wood.

Tabela 2-Efeito da pré-vaporização no teor de umidade inicial de tábuas de Eucalyptus dunnii.

\begin{tabular}{cccc}
\hline \multirow{2}{*}{$\begin{array}{c}\text { Number of } \\
\text { replications }\end{array}$} & \multicolumn{2}{c}{ Initial moisture content $(\%)$} & $\begin{array}{c}\text { Reduction } \\
(\%)\end{array}$ \\
\cline { 2 - 3 } 1 & Untreated & Pre-steamed & 14.0 \\
2 & 74.5 & 64.1 & 11.1 \\
3 & 84.0 & 74.7 & 27.4 \\
4 & 83.1 & 60.3 & 1.5 \\
5 & 103.1 & 101.6 & 16.2 \\
6 & 88.2 & 73.9 & 10.7 \\
7 & 76.4 & 68.2 & 9.7 \\
8 & 75.9 & 68.5 & 9.6 \\
9 & 86.5 & 78.2 & 0.2 \\
10 & 84.0 & 83.8 & 0.3 \\
11 & 67.5 & 67.3 & 1.0 \\
Average & 88.2 & 87.3 & $9.2 *$ \\
mean & 82.9 & 75.3 & \\
\hline
\end{tabular}

Where $*$ - significant difference at $5 \%$ level of significance by t-test paired; ns - no significant difference.

JUNIOR, 1968). According to Ellwood and Erickson (1962), the decrease of moisture content from the wood occurs in three phases: (1) in the temperature increase during the heating period, (2) when the timber reaches the boiling point of water due to the expansion of air bubbles, and (3) during the wood cooling at atmosphere temperature. These results are similar to those obtained by Campbell (1961) and Chafe (1990), who concluded that the pre-steaming on Eucalyptus provided reductions in the initial moisture content from 5 to $20 \%$ in function to the kind of wood.

\subsection{Effect of steaming on the drying rate}

Table 3 shows the average values for the drying rates and the determination coefficients from the regression models adjusted to determine the moisture content to untreated and steamed boards as a function of drying time of $E$. dunnii in electric oven.

As can be seen in Table 3, the drying curves of both treatments were adjusted perfectly to the regression model utilized. The linear regression equations that represent original data had determination coefficients $\left(R^{2}\right)$ between 95 and $99 \%$ and, therefore, could be used to estimate the 
Table 3 - Effect of pre-steaming on the drying rate of E. dunnii wood.

Tabela 3 - Efeito da pré-vaporização na taxa de secagem de tábuas de E. dunnii.

\begin{tabular}{|c|c|c|c|c|c|c|c|c|c|}
\hline \multirow[b]{2}{*}{$\mathrm{N}$} & \multicolumn{4}{|c|}{ Untreated } & \multicolumn{4}{|c|}{ Pre-steamed } & \multirow{2}{*}{$\begin{array}{l}\text { Increase of } \\
\text { the drying } \\
\text { rate }(\%)\end{array}$} \\
\hline & $\begin{array}{c}\text { IMC } \\
(\%)\end{array}$ & $\begin{array}{c}\text { FMC } \\
(\%)\end{array}$ & $\begin{array}{l}\text { Drying } \\
\text { rate }\end{array}$ & $\begin{array}{l}\mathrm{R}^{2} \\
(\%)\end{array}$ & $\begin{array}{c}\text { IMC } \\
(\%)\end{array}$ & $\begin{array}{c}\text { FMC } \\
(\%)\end{array}$ & $\begin{array}{c}\text { Drying } \\
\text { rate }\end{array}$ & $\begin{array}{l}\mathrm{R}^{2} \\
(\%)\end{array}$ & \\
\hline 1 & 74.5 & 3.0 & 0.008141 & 95.0 & 64.1 & 4.3 & 0.008164 & 97.1 & 0.3 \\
\hline 2 & 84.0 & 5.9 & 0.006887 & 99.0 & 74.7 & 5.0 & 0.007197 & 98.0 & 4.5 \\
\hline 3 & 83.1 & 7.7 & 0.006060 & 99.0 & 60.3 & 5.8 & 0.006410 & 97.0 & 5.8 \\
\hline 4 & 103.1 & 5.4 & 0.007222 & 98.7 & 101.6 & 4.7 & 0.008064 & 97.6 & 11.7 \\
\hline 5 & 88.2 & 5.7 & 0.007246 & 98.3 & 73.9 & 4.9 & 0.007478 & 98.6 & 3.2 \\
\hline 6 & 76.4 & 5.4 & 0.006371 & 98.6 & 68.2 & 5.4 & 0.007045 & 96.0 & 10.6 \\
\hline 7 & 75.9 & 7.2 & 0.005979 & 98.2 & 68.5 & 6.3 & 0.006468 & 97.0 & 8.2 \\
\hline 8 & 86.5 & 5.1 & 0.007210 & 99.0 & 78.2 & 5.3 & 0.007240 & 98.0 & 0.4 \\
\hline 9 & 84.0 & 9.4 & 0.005680 & 98.0 & 83.8 & 8.6 & 0.005720 & 98.0 & 0.7 \\
\hline 10 & 67.5 & 7.3 & 0.005960 & 99.0 & 67.3 & 5.1 & 0.006890 & 97.4 & 15.6 \\
\hline 11 & 88.2 & 7.6 & 0.006560 & 98.0 & 87.3 & 6.8 & 0.007040 & 96.0 & 7.3 \\
\hline Mean & & & 0.006665 & & & & 0.007065 & & $6.2 *$ \\
\hline
\end{tabular}

Where $\mathrm{N}$ - number of replications; IMC - initial moisture content; FMC - final moisture content; * - significant difference at 5\% level of significance by t-test paired; ns - no significant difference.

drying rate from $E$. dunnii boards. Figure 2 allows better visualization of drying rate by fitting of simple linear regression model.

It is verified, also in Table 3 , that the drying rate in steamed boards was higher than in untreated boards. The thermal treatment with steam caused a significant increase in the drying rate of $6.2 \%$ for $E$. dunnii boards. Similar behavior was showed by Alexiou et al. (1990), Matsumura et al. (1999) and Simpson (1975), who steamed other kinds of wood.

This study also showed that the increase on drying rate from E. dunni by thermal treatment was lower than those obtained for steamed E. pilularis boards, which exhibited an increase between 7 and 16\% when compared with the untreated boards (ALEXIOU et al., 1990). However, in the referenced study, the wood drying process was carried out in an oven with forced air ventilation and the moisture loss caused by the thermal treatment was added at the drying rate of $E$. pilularis.

The behavior of drying rate in steamed boards when dried on pilot kiln is shown in Figure 3. As can be seen, the drying curves were perfectly adjusted to the regression model utilized. The linear regression that represents the data had determination coefficients $\left(R^{2}\right)$ of $98.84 \%$ and therefore can be used to estimate the drying rate from steamed E. dunnii boards.
It is verified that the drying rate from steamed boards from green to $17 \%$ moisture content was 0.008200 and therefore about $16 \%$ higher than the steamed boards dried in electric oven $(0.007065)$. This result was expected since the kiln-drying process is carried out with forced air ventilation and continuous increase of temperature.

Another important observation is that drying rate from 17 to $12 \%$ moisture content was higher than in initial phase from drying wood. However was applied steam at $100^{\circ} \mathrm{C}$ for 5 hours, when the wood presented $17 \%$ moisture content to recovery of collapse. This procedure increased the drying rate to 0.03430 , which presents four times higher than the drying rate from green to $17 \%$ moisture content.

However, the significant increase in the drying rate from E. dunnii steamed when compared to untreated boards can possibly be attributed to increased in the permeability of the warts layer and accessibility to the $\mathrm{S}_{3}$ layer from the cell wall, the thermal degradation by acid hydrolysis of the chemical components from the cell walls, and the mobilization and partial removal of extractives during steaming. According by Alexiou et al. (1990), Kininmonth (1971), Mackay (1971), Matsumura et al. (1999), Salud (1976) and Zhang and Cai (2008) these phenomena allow greater access of water molecules to cell walls resulting increasing the drying rate.

Cerne, Lavras, v. 19, n. 4, p. 637-645, out./dez. 2013 

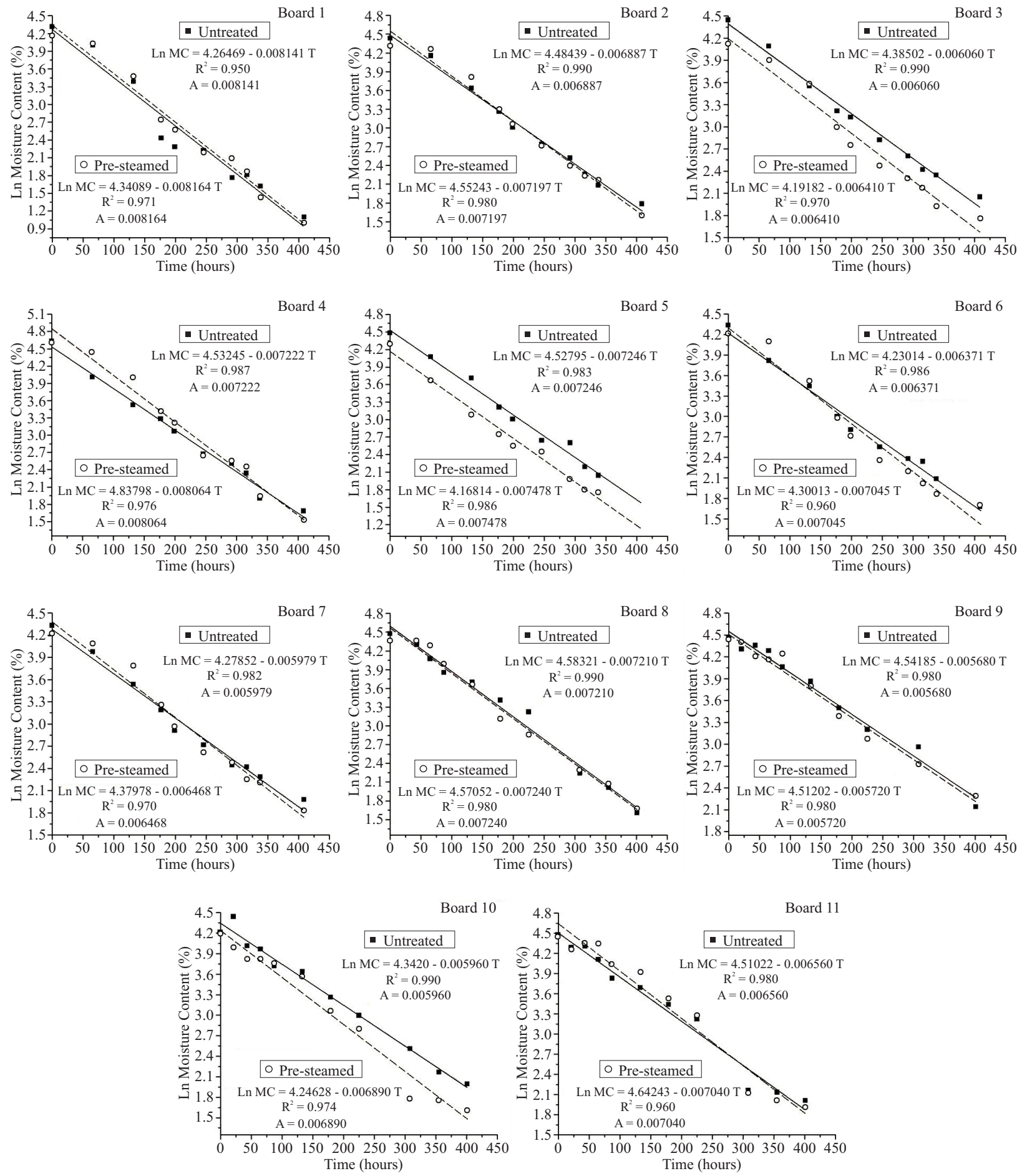

Figure 2 - Drying curves and drying rates in pre-steamed and untreated boards of Eucalyptus dunnii dried in oven.

Figura 2 - Curvas de secagem e taxas de secagem em tábuas controle e pré-vaporizadas de Eucalyptus dunnii durante a secagem em estufa elétrica.

Cerne, Lavras, v. 19, n. 4, p. 637-645, out./dez. 2013 


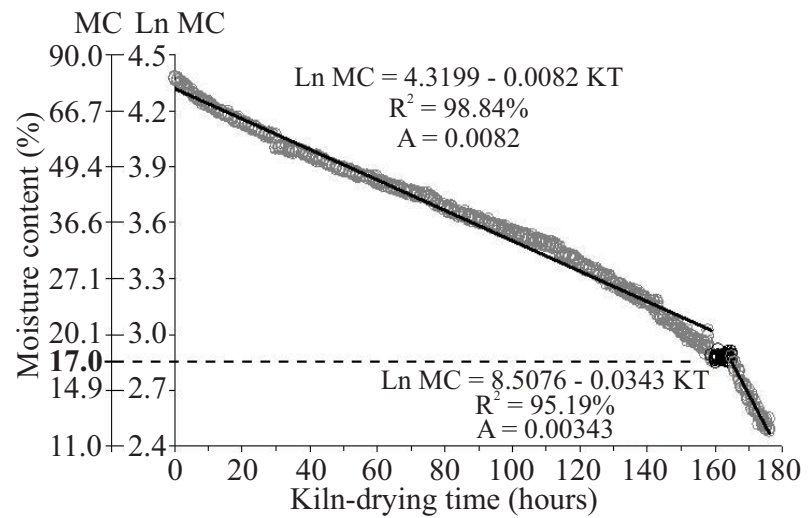

Figure 3 - Drying curves and drying rate in boards of Eucalyptus dunnii dried in kiln.

Figura 3-Curvas de secagem e taxas de secagem em tábuas de Eucalyptus dunnii durante a secagem convencional.

\subsection{Effect of steaming on the moisture gradient}

Table 4 shows the average values for the moisture gradient from untreated and steamed boards of E. dunnii.

Table 4 - Effect of pre-steaming on the moisture gradient of $E$. dunnii wood.

Tabela 4 - Efeito da pré-vaporização no gradiente de umidade de tábuas de E. dunnii.

\begin{tabular}{cccccc}
\hline \multirow{2}{*}{ References } & \multicolumn{2}{c}{ Untreated } & \multicolumn{2}{c}{ Pre-steamed } & Reduction \\
\cline { 2 - 5 } & $\mathrm{N}$ & $\begin{array}{c}\text { Moisture } \\
\text { gradient (\%) }\end{array}$ & $\mathrm{N}$ & $\begin{array}{c}\text { Moisture } \\
\text { gradient (\%) }\end{array}$ & $(\%)$ \\
\hline $3-1$ & 20 & 21.1 & 20 & 17.8 & $15.6^{*}$ \\
$3-2$ & 20 & 5.4 & 20 & 4.6 & $14.8^{*}$ \\
\hline
\end{tabular}

Where $\mathrm{N}$ - number of replications; * - significant difference at $5 \%$ significance level by t-test paired; ns - no significant difference; reference 3-1 - moisture gradient between the outer layers and the center of the sample; reference 3-2 - moisture gradient between the intermediate layers and the center of the sample.

It is observed that the steamed boards from E. dunnii presented the lower moisture gradient than untreated boards. This behavior applies to both between the outer layers and the center of the boards (between references 3 and 1) as between the intermediate layers and the center of the board (between references 3 and 2).

There was a significant reduction in the moisture gradient between the outer layers and center of the boards (between references 3 and 1 ) of $15.6 \%$ with steaming. The same thermal treatment caused significant reductions of $14.8 \%$ in the moisture gradient between the intermediate layers and the center of the boards (between references 3 and 2). Similar results were reported by Avramidis and Oliveira (1993), Campbell (1961), Ellwood and Erickson (1962), Guoxing et al. (2003) and Simpson (1976), who studied the effect of steaming on the wood of other species.

The increase in the diffusion coefficient from steamed wood appears to be primarily responsible for reducing the moisture gradient (ALEXIOU et al., 1990; KININMONTH, 1971). These results are similar with those reported by Mackay (1971), who found an increase in the diffusion coefficient between 7 and $12 \%$ in steamed boards from E. regnans.

\section{CONCLUSIONS}

Based on the results, the following effects of thermal treatment with steam on E. dunnii boards were observed: (1) the initial moisture content were significantly reduced by $9.2 \%$; (2) the drying rate was significantly increased by $6.2 \%$; (3) steamed boards in an oven showed drying rate of 0.007065 whereas in kiln were 0.008200 and 0.034300 from green to 17 and 17 to $12 \%$ moisture content, respectively; and (4) the moisture gradient between the outer layer and the center of boards was significantly decreased by $15.6 \%$ and between the outer and intermediate layers was decreased by $14.8 \%$. It was demonstrated that the steaming prior to drying can be suitable for reduces the drying times of this kind of wood.

\section{ACKNOWLEDGMENTS}

The authors thank the Research Assistance Foundation from São Paulo (FAPESP), Brazil, for financial support of this research through grant numbers 00/02165-7 and $02 / 05028-6$.

\section{REFERENCES}

ALEXION, P. N.; WILKINS, A. P.; HARTLEY, J. Effect of pres-teaming on drying rate, wood anatomy and shrinkage of regrowth Eucalyptus pilularis Sm. Wood Science and Technology, New York, v. 24, n. 1, p. 103-110, Mar. 1990.

AVRAMIDIS, S.; OLIVEIRA, L. Influence of presteaming on Kiln-drying of thick hem fir lumber. Forest Products Journal, Madison, v. 43, n. 11/12, p. 7-12, Nov./ Dec. 1993.

Cerne, Lavras, v. 19, n. 4, p. 637-645, out./dez. 2013 
CALONEGO, F. W.; SEVERO, E. T. D. Efeito da posição diametral das tábuas e da vaporização nos defeitos de secagem de Eucalyptus grandis. Cerne, Lavras, v. 13, n. 1, p. 10-18, jan./mar. 2007.

CALONEGO, F. W.; SEVERO, E. T. D. Efeito da vaporização de toras na secagem da madeira de Eucalyptus grandis.

Floresta Ambiente, Seropédica, v. 11, n. 1, p. 7-13, ago./dez. 2004.

CALONEGO, F. W.; SEVERO, E. T. D.; CUNHA, A. R.; GAIA, D. C. Use of glass transition temperature for stabilization of boards cracks of Eucalyptus grandis. Anais da Academia Brasileira de Ciências, Rio de Janeiro, v. 82, n. 3, p. 1-7, jul./set. 2010.

CAMPBELL, G. S. The value of pre-steaming for drying some collapse-susceptible Eucalypts. Forest Products Journal, Madison, v. 11, n. 8, p. 334-337, Aug. 1961.

CHAFE, S. C. Effect of brief presteaming on shrinkage, collapse and other wood-water relationships in Eucalyptus regnans F Muell. Wood Science and Technology, New York, v. 24, n. 4, p. 311-326, Oct. 1990.

ELLWOOD, E. L.; ERICKSON, R. W. Effect of pre-steaming on seasoning stain and drying rate of redwood. Forest Products Journal, Madison, v. 12, n. 7, p. 328-332, July 1962.

ELLWOOD, E. L.; ECKLUND, B. A. Treatments to improve wood permeability as an approach to the drying problems. In: WESTERN DRY KILN CLUBS ANNUAL MEETING, 13., 1961, Medford. Proceedings... Medford: Western Dry Kiln Clubs, 1961. p. 5-9.

FOOD AND AGRICULTURE ORGANIZATION OF THE UNITED NATIONS. EI eucalipto en la repoblacion forestal. Rome, 1981. $723 \mathrm{p}$.

GOLFARI, L.; PINHEIRO NETO, F. A. Escolha de espécies de eucalipto potencialmente aptas para diferentes regiões do Brasil. Brasil Florestal, Rio de Janeiro, v. 1, n. 3, p. 17-38, jul./set. 1970.

GUOXING, D.; LIANBAI, G.; ZHENDENG, Z. Study on drying strategies for Eucalyptus lumber with $25 \mathrm{~mm}$ thickness. In: INTERNATIONAL IUFRO WOOD DRYING

Cerne, Lavras, v. 19, n. 4, p. 637-645, out./dez. 2013
CONFERENCE, 8., 2003, Brasov. Proceedings... Brasov: IUFRO, 2003. p. 209-211.

HILDEBRAND, R. Kiln drying of saw timber. Berlin: R. H. Maschinenbau Gmbh, 1970. 202 p.

KININMONTH, J. A. Effect of steaming on the fine structure of Nothofagus fusca (Hook, F.) Oerst. New Zealand Journal Forest Science, Rotorua, v. 1, p. 129-139, 1971.

KOLlMANN, F. F. P.; CÔTE JUNIOR, W. A. Principles of wood science and technology: I., solid wood. New York: Springer-Verlag, 1968. 592 p.

MACKAY, J. F. G. Influence of steaming on water vapor diffusion in hardwoods. Wood Science, Madison, v. 4, n. 3, p. 156-160, 1971.

MATSUMURA, J.; BOOKER, R. E.; RIDOUTT, B. G.; DONALDSON, L. A.; MIKAJIRI, N.; MATSUNAGA, H.; ODA, K. Impregnation of radiata pine wood by vacuum treatment II: effect of pré-steaming on wood structure and resin content. Journal of Wood Science, Tokyo, v. 45, n. 6, p. 456-462, Dec. 1999.

NICHOLAS, D. D.; THOMAS, R. J. Influence of steaming on ultra structure of bordered pit membrane in loblolly pine. Forest Products Journal, Madison, v. 8, n. 1, p. 57-59, Jan. 1968.

SALUD, E. C. Comparison of the quality and composition of the wood extractives of unsteamed and steamed apitang (Dipterocarpus grandiflorus Blanco). Pterocarpus, v. 2, p. 123-134, 1976.

SEVERO, E. T. D. Qualidade da secagem de madeira de Eucalyptus dunnii. Ciência Florestal, Santa Maria, v. 10, n. 1, p. 109-124, jan./jun. 2000 .

SEVERO, E. T. D.; CALONEGO, F. W.; MATOS, C. A. O. Lumber quality of Eucalyptus grandis as a function of diametrical position and log steaming. Bioresource Technology, London, v. 101, n. 7, p. 2545-2548, July 2010.

SIMPSON, W. T. Effect of pre-steaming on moisture gradient of Northern Red Oak during drying. Wood Science, Madison, v. 8, n. 4, p. 156-159, 1976. 
SIMPSON, W. T. Effect of steaming on the drying rate of several species of wood. Wood Science, Madison, v. 7, p. 247-255, 1975.

SOUZA, J. T.; TREVISAN, R.; DENARDI, L.; STANGERLIN, D. M.; VIVIAN, M. A.; HASELEIN, C. R.; SANTINI, E. J. Qualidade da secagem de madeira de Eucalyptus dunnii. Cerne, Lavras, v. 18, n. 1, p. 167-174, jan./mar. 2012.

VERMAAS, H. F. Drying eucalypts for quality: material characteristics, pré-drying treatments, drying methods, schedules and optimization of drying quality. SuidAfrikaanse Bosboutydskrif, Pretoria, n. 174, p. 41-49, 1995.

WEIK, B. B.; WENGERT, E. M.; SCHROEDER, J.;

BRISBIN, R. Practical drying techniques for yellow-poplar S-D-R flinches. Forest Products Journal, Madison, v. 34, n. 7/8, p. 39-44, July/Aug. 1984.

ZHANG, Y.; CAI, L. Impact of heating speed on permeability of sub-alpine fir. Wood Science and Technology, New York, v. 42, n. 3, p. 241-250, Mar. 2008.

Received: July 6, 2011; accepted: May 24, 2013.

Cerne, Lavras, v. 19, n. 4, p. 637-645, out./dez. 2013 
